\title{
ANALISIS PENGARUH KUALITAS PELAYANAN TERHADAP KEPUASAN NASABAH PADA PT. BANK NEGARA INDONESIA TBK KANTOR KAS BINUANG
}

\author{
Fajar Ari Rohan \\ Sekolah Tinggi Ilmu Ekonomi Pancasetia Banjarmasin \\ J1. Ahmad Yani Km. 5.5 Banjarmasin \\ fajar.ari.rohan@gmail.com
}

\begin{abstract}
Abstrak : Penelitian ini bertujuan untuk mengetahui pengaruh kualitas pelayanan berpengaruh signifikan terhadap kepuasan nasabah pada PT. Bank Negara Indonesia Tbk Kantor Kas Binuang. Penulis menggolongkan penelitian ini pendekatan analisis kuantitatif untuk mengolah data primer yang diperoleh dari sampel penelitian sebanyak 100 nasabah. Hasil penelitian dapat disimpulkan bahwa terdapat pengaruh yang positif dan signifikan antara kualitas pelayanan terhadap kepuasan nasabah pada PT. Bank Negara Indonesia Tbk Kantor Kas Binuang dengan nilai Y $=1.668+$ $0.626 \mathrm{X}+0.291$. Jika kualitas pelayanan semakin meningkat maka kepuasan nasabah PT. Bank Negara Indonesia Tbk Kantor Kas Binuang juga akan meningkat, sebaliknya jika kualitas pelayanan yang ada di PT. Bank Negara Indonesia Tbk Kantor Kas Binuang semakin menurun maka kepuasan nasabah juga dapat menurun.
\end{abstract}

Kata Kunci : Kualitas Pelayanan, Kepuasan Nasabah Bank

Abstract : This study aims to determine the effect of service quality has a significant effect on customer satisfaction at PT. Bank Negara Indonesia Tbk Binuang Cash Office. The author classifies this research as a quantitative analysis approach to processing primary data obtained from a research sample of 100 customers. The result of this research can be concluded that there is a positive and significant influence between service quality and customer satisfaction at PT. Bank Negara Indonesia Tbk Binuang Cash Office with a value of $Y=1.668+0.626 X+0.291$. If the quality of service increases, the customer satisfaction of PT. Bank Negara Indonesia Tbk Binuang Cash Office will also improve, on the contrary if the quality of service available at PT. Bank Negara Indonesia Tbk Binuang Cash Office is decreasing, so customer satisfaction can also decrease.

Keywords: Service Quality, Bank Customer Satisfaction 


\section{Latar Belakang Masalah}

Kualitas layanan berarti seberapa jauh perbedaan antara kenyataan dengan harapan pelanggan atas layanan yang mereka terima. Atau dapat juga didefinisikan sebagai hasil persepsi dari perbandingan antara harapan pelanggan dengan kinerja aktual layanan. Dari kedua pendapat diatas dapat diketahui bahwa ada 2 unsur utama dalam kualitas layanan/jasa yaitu layanan yang diharapkan dan layanan yang diterima.

Dimensi kualitas jasa yang digunakan oleh pelanggan dalam menilai kualitas pelayanan pada industri jasa, keandalan yaitu sejauh mana penyedia jasa mampu memberikan apa yang telah dijanjikan secara akurat, terpercaya dan dapat diandalkan kepada konsumen, ketanggapan yaitu menekankan kepada sikap diri penyedia jasa yang penuh perhatian, cepat dan tepat dalam menghadapi permintaan, pertanyaan, dan masalah konsumen, jaminan yaitu pengetahuan dan keramahan serta kemampuan karyawan dalam melaksanakan tugas dengan baik sehingga menimbulkan keyakinan dan kepercayaan dari konsumen, empati yaitu kesediaan para karyawan untuk peduli, serta bagaimana karyawan memberikan perhatian yang bersifat pribadi guna menumbuhkan rasa keakraban yang positif, berwujud yaitu penampilan fisik, fasilitas, petugas, serta materi komunikasi yang disajikan pihak perusahaan untuk melayani para pelanggannya.

Persaingan dalam dunia bank ini semakin hari semakin ketat, sehingga setiap usaha yang dijalankan oleh suatu bank banyak mengalami hambatan-hambatan. Untuk mengatasi hal ini, bank harus dapat membentuk suatu strategi bisnis yang baik. Ada kesadaran bahwa kepuasan nasabah sangat penting guna menjamddddin kelangsungan hidup suatu bank, maka bank merasa perlu untuk memenuhi segala keinginan dan harapan nasabah. Persaingan di bidang perbankan ini bukan hal yang baru, dimana jumlah bank sudah sangat banyak. Demikian juga dengan banyaknya masyarakat Indonesia yang merasa mereka membutuhkan bank. Hal ini membuka peluang bagi setiap bank untuk dapat memberikan pelayanan yang terbaik agar masyarakat mempercayai bank tersebut. Perbankan dituntut perlu meningkatkan kualitas jasa layanan dalam meningkatkan kepuasan nasabah sehingga dapat bersaing secara sehat antara bank-bank umum lainnya. Maka dari itu penting untuk menganalisa kualitas layanan perbankan.

PT. Bank Negara Indonesia Tbk Kantor Kas Binuang merupakan industri jasa yang bergerak dalam bidang keuangan, dimana mengharuskan perusahaan untuk dapat meningkatkan kualitas jasa demi mencapai peringkat yang lebih baik dimasa yang akan datang. Untuk memenuhi harapan tersebut PT. Bank Negara Indonesia Tbk Kantor Kas Binuang harus mampu menawarkan kualitas pelayanan yang lebih baik bagi nasabah yaitu dengan meminimalisir ketidaksesuaian kinerja pelayanan terhadap harapan nasabah atas jasa yang akan nasabah gunakan.

Untuk mencapai hal tersebut PT. Bank Negara Indonesia Tbk Kantor Kas Binuang harus mampu menerapkan enam dimensi kualitas jasa yang berorientasi kepada kinerja manajemen dan kepentingan nasabah khususnya jasa perbankan meliputi compliance, asurrance, reliability, tangible, emphaty dan responsiveness. Jika hal ini dapat dijalankan maka PT. Bank Negara Indonesia Tbk Kantor Kas Binuang akan memberikan keunggulan bersaing dalam industri perbankan. Kondisi ini tentunya akan berperan dalam memberikan persaingan baru bagi industri perbankan di Indonesia.

Layanan merupakan unsur yang tidak dapat dipisahkan bagi setiap kegiatan PT. Bank Negara Indonesia Tbk Kantor Kas Binuang dalam menawarkan, menjual dan memproses suatu produk karena layanan difokuskan dalam rangka menuju kepuasan nasabah akan produk dari BNI, melalui layanan 24 jam, menyediakan wadah komunikasi bagi para nasabah maupun calon nasabah yang dapat dimanfaatkan setiap waktu untuk informasi mengenai BNI dan produk-produknya. Semua dilakukan PT. Bank Negara Indonesia Tbk Kantor Kas Binuang dalam rangka memberikan kualitas pelayanan 
yang terbaik untuk memuaskan nasabah serta membangun loyalitas nasabah.

Ketidakpuasan nasabah selama ini pada PT. Bank Negara Indonesia Tbk Kantor Kas Binuang dipengaruhi oleh pelayanan yang dilakukan oleh perusahaan seperti keluhan terhadap karyawan yang tidak memberikan informasi secara jelas tentang produk-produk BNI46 (simpanan Taplus, BNI Bisnis, BNI Tappa dan Tamma, BNI Haji dan lain sebagainya), layanan ATM sering terganggu dan lain sebagainya sehingga hal ini tentunya akan berdampak pada nasabah untuk mencari jasa perbankan yang lebih baik dari PT. Bank Negara Indonesia Tbk Kantor Kas Binuang.

\section{Landasan Teori}

Kepuasan Konsumen

Dewasa ini perhatian terhadap kepuasan maupun ketidakpuasan konsumen telah semakin besar karena pada dasarnya tujuan dari suatu perusahaan adalah untuk menciptakan rasa puas pada konsumen. Semakin tinggi tingkat kepuasan konsumen, maka akan mendatangkan keuntungan yang semakin besar bagi perusahaan, karena konsumen akan melakukan pembelian ulang terhadap produk perusahaan. Namun, apabila tingkat kepuasan yang dirasakan konsumen kecil, maka terdapat kemungkinan bahwa konsumen tersebut akan pindah ke produk pesaing.

Menurut Kotler dan Keller (2014:252), kepuasan adalah tingkat perasaan seseorang setelah membandingkan kinerja atau hasil yang dia rasakan dibandingkan dengan harapannya.

Sedangkan menurut Lupiyoadi (2016:349) kepuasan atau ketidakpuasan konsumen adalah respon konsumen terhadap evaluasi ketidaksesuaian (disconfirmation) yang dirasakan antara harapan sebelumnya dan kinerja aktual produk yang dirasakan setelah pemakaiannya.

Suatu tanggapan emosional pada evaluasi terhadap pengalaman konsumsi suatu produk atau jasa. Kepuasan konsumen merupakan evaluasi purna beli dimana alternatif yang dipilih sekurang-kurangnya sama atau melampaui harapan konsumen, sedangkan ketidakpuasan timbul apabila hasil (outcome) tidak memenuhi harapan.

Kepuasan konsumen terhadap suatu produk ataupun jasa, sebenarnya sesuatu yang sulit untuk didapat jika perusahaan jasa atau industri tersebut tidak benar-benar mengerti apa yang diharapkan oleh konsumen. Untuk produk atau layanan dengan kualitas yang sama, dapat memberikan tingkat kepuasan yang berbedabeda bagi konsumen yang berbeda. Oleh karena itu, suatu perusahaan harus selalu memperhatikan kualitas produk maupun pelayanan yang diberikan kepada konsumen.

Kepuasan konsumen merupakan respons konsumen terhadap ketidaksesuaian antara tingkat kepentingan sebelumnya dan kinerja aktual yang dirasakannya setelah pemakaian. Kepuasan konsumen dipengaruhi oleh persepsi kualitas jasa, kualitas produk, harga dan faktorfaktor yang bersifat pribadi serta yang bersifat situasi sesaat.

Kualitas Jasa Pelayanan

Modernitas dengan kemajuan teknologi akan mengakibatkan persaingan yang sangat ketat untuk memperoleh dan mempertahankan konsumen. Kualitas pelayanan menjadi suatu keharusan yang harus dilakukan perusahaan supaya mampu bertahan dan tetap mendapat kepercayaan konsumen. Pola konsumsi dan gaya hidup konsumen menuntut perusahaan mampu memberikan pelayanan yang berkualitas. Keberhasilan perusahaan dalam memberikan pelayanan yang berkualitas dapat ditentukan dengan pendekatan service quality.

Service quality adalah seberapa jauh perbedaan antara harapan dan kenyataan para konsumen atas layanan yang mereka terima. Service quality dapat diketahui dengan cara membandingkan persepsi konsumen atas layanan yang benar-benar mereka terima dengan layanan sesungguhnya yang mereka harapkan. Kualitas pelayanan menjadi hal utama yang diperhatikan serius oleh perusahaan, yang melibatkan seluruh sumber daya yang dimiliki perusahaan. Definisi mutu jasa berpusat pada pemenuhan kebutuhan dan keinginan konsumen serta ketepatan 
penyampaian untuk mengimbangi harapan konsumen.

Menurut Lupiyoadi (2016:183), kualitas jasa adalah tingkat keunggulan yang diharapkan dan pengendalian atas tingkat keunggulan untuk memenuhi keinginan konsumen. Apabila jasa yang diterima sesuai dengan yang diharapkan, maka kualitas jasa dipersepsikan baik dan memuaskan. Jika jasa yang diterima melampaui harapan konsumen, maka kualitas jasa dipersepsikan ideal. Sebaliknya jika jasa yang diterima lebih rendah dari pada yang diharapkan, maka kualitas jasa dianggap buruk.

Mengacu pada pengertian kualitas layanan tersebut maka konsep kualitas layanan adalah suatu daya tanggap dan realitas dari jasa yang diberikan perusahaan. Kualitas pelayanan harus dimulai dari kebutuhan konsumen dan berakhir pada persepsi konsumen, hal ini berarti bahwa kualitas yang baik bukanlah berdasarkan persepsi penyediaan jasa, melainkan berdasarkan persepsi konsumen.

Kualitas layanan mengacu pada penilaian konsumen tentang inti pelayanan, yaitu si pemberi pelayanan itu sendiri atau keseluruhan organisasi pelayanan, sebagian besar masyarakat sekarang mulai menampakkan tuntutan terhadap pelayanan prima, mereka bukan lagi sekedar membutuhkan produk yang bermutu tetapi mereka lebih senang menikmati kenyamanan pelayanan. Oleh karena itu, dalam merumuskan strategi dan program pelayanan, organisasi harus berorientasi pada kepentingan konsumen dan sangat memperhatikan dimensi kualitasnya.

Meningkatkan kualitas pelayanan merupakan hal yang sangat penting agar dapat menghadapi persaingan yang semakin ketat dan tetap eksis di era globalisasi. Banyak faktor yang harus dipertimbangkan dalam meningkatkan kualitas pelayanan karena hal ini akan berdampak baik langsung maupun tidak langsung terhadap organisasi secara keseluruhan.

Menurut Othman dan Owen (2016:6), mengembangkan model carter yang merupakan suatu pengukuran kualitas layanan perbankan meliputi :

1. Compliance merupakan komponen yang berkaitan dengan kepuasan atas layanan yang diterima oleh konsumen.

2. Assurance terdiri dari beberapa komponen antara lain komunikasi, kredibilitas, keamanan, kompetensi dan sopan santun.

3. Reability merupakan kemampuan perusahaan untuk memberikan pelayanan sesuai yang dijanjikan secara akurat dan terpercaya.

4. Tangible merupakan penampilan dan kemampuan sarana dan prasarana fisik perusahaan dan keadaan lingkungan sekitarnya adalah bukti nyata dan pelayanan yang diberikan.

5. Emphaty merupakan memberikan perhatian yang tulus dan bersifat individual atau pribadi yang diberikan kepada para konsumen dengan berupaya memahami keinginan konsumen.

6. Responsiveness merupakan suatu kemauan untuk membantu dan memberikan pelayanan yang cepat dan tepat kepada konsumen, dengan penyampaian informasi yang jelas.

\section{Metode Penelitian}

Jenis penelitian dalam penyusunan skripsi ini menggunakan pendekatan analisis kuantitatif untuk mengolah data primer yang diperoleh dari sampel penelitian. Penelitian ini ditujukan untuk mencari seberapa besar pengaruh faktor kualitas pelayanan yang mempengaruhi kepuasan nasabah (tangible (X1), reliability (X2), responsiveness (X3), assurance (X4), dan empathy (X5)) pada PT. Bank Negara Indonesia Tbk Kantor Kas Binuang dan mengidentifikasi variabel yang dominan kepuasan nasabah di PT. Bank Negara Indonesia Tbk Kantor Kas Binuang tersebut.

Sehubungan dengan masalah yang dikemukakan sebelumnya, maka akan dilakukan analisa berdasarkan data yang diperoleh dengan menggunakan peralatan analisis sebagai berikut : 
1. Uji Reliabilitas adalah data untuk mengukur suatu kuesioner yang merupakan indikator dari variabel atau konstruk. Suatu kuesioner dikatakan reliabel atau handal jika jawaban seseorang terhadap pernyataan adalah konsisten atau stabil dari waktu ke waktu. Kehandalan yang menyangkut kekonsistenan jawaban jika diujikan berulang pada sampel yang berbeda. SPSS memberikan fasilitas untuk mengukur realibilitas dengan uji statistik Cronbach Alpha ( $\alpha$ ). Suatu konstruk atau variabel dikatakan reliabel jika memberikan nilai Cronbach Alpha > 0,60.

2. Uji Validitas digunakan untuk mengukur sah (valid) atau tidaknya suatu kuesioner. Suatu kuesioner dikatakan valid jika pertanyaan pada kuesioner mampu untuk mengungkap sesuatu yang akan diukur oleh kuesioner tersebut. Uji Validitas dihitung dengan membandingkan nilai $\mathrm{r}$ hitung (correlated item - total correlation) dengan nilai $r$ tabel. Jika $r$ hitung $>r$ tabel dan nilai positif maka butir atau pertanyaan tersebut dinyatakan valid.

3. Analisis Regresi Linear Sederhana. Analisis statistik yang digunakan dalam penelitian ini adalah menggunakan analisis regresi linear dengan program SPSS. Analisis regresi sederhana untuk menghitung besarnya pengaruh secara kuantitatif dari suatu perubahan kejadian (variabel $\mathrm{X}$ ) terhadap kejadian lainnya (variabel Y). dalam penelitian ini, analisis regresi berperan sebagai teknik statistik yang digunakan untuk menguji ada tidaknya pengaruh kualitas pelayanan (X) terhadap kepuasan nasabah (Y).

Menurut Rangkuty (2014:23-25) formulasi regresi linear sederhana adalah sebagai berikut: $\mathbf{Y}=\mathbf{a}+\mathbf{b} . \mathbf{X}+\mathbf{e}$

Dimana :

$\mathrm{Y}=$ Kepuasan Nasabah

$\mathrm{a}=$ Konstanta

$\mathrm{b}=$ Koefisien

$\mathrm{X}=$ Kualitas Pelayanan

$\mathrm{e}=$ Standar Kesalahan (Error)

\section{Hasil Penelitian dan Pembahasan}

Kualitas pelayanan berpengaruh signifikan terhadap kepuasan nasabah pada PT. Bank Negara Indonesia Tbk Kantor Kas Binuang Menurut Tjiptono (2017:130) mengemukakan bahwa kualitas pelayanan sebagai ukuran seberapa bagus tingkat layanan yang diberikan mampu sesuai dengan ekspetasi nasabah/pelanggan. Kualitas pelayanan bias diwujudkan melalui pemenuhan dan keinginan nasabah serta ketepatan penyampaiannya untuk mengimbangi harapan nasabah, maka kualitas pelayanan tersebut akan dipersepsikan baik atau positif oleh nasabah. Begitu juga sebaliknya, apabila pelayanan yang dirasakan lebih jelek dari yang diharapkan, maka kualitas pelayanan dipersepsikan negative atau buruk.

Berdasarkan analisis data yang telah diuji dalam penelitian ini, maka dapat dijelaskan bahwa ada pengaruh yang positif dan signifikan antara kualitas pelayanan terhadap kepuasan nasabah. Jika kualitas pelayanan semakin meningkat maka kepuasan nasabah juga akan semakin tinggi. Hal ini terbukti dari hasil analisis uji t yang menunjukkan nilai thitung sebesar 9,325 dengan taraf signifikansi.

Hal tersebut didukung dengan penelitian yang dilakukan oleh Cristiana Akky Augusta Lovenia (2016), Bagus Tri Leksono (2014) dan Dodik Agung (2014) yang menunjukkan hasil bahwa kualitas pelayanan berpengaruh yang positif dan signifikan terhadap kepuasan nasabah.

Dengan demikian, dari penjelasan secara teori dan hasil statitistik diketahui bahwa kualitas pelayanan memiliki pengaruh yang positif dan signifikan terhadap kepuasan nasabah pada PT. Bank Negara Indonesia Tbk Kantor Kas Binuang. Dengan adanya peningkatan kualitas pelayanan dari PT. Bank Negara Indonesia Tbk Kantor Kas Binuang, maka hal tersebut dapat mempengaruhi kepuasan nasabah sehingga nasabah akan semakin merasa senang dan puas terhadap pelayanan yang diberikan dan dilakukan oleh pihak PT. Bank Negara Indonesia Tbk Kantor Kas Binuang.

\section{Penutup}


Berdasarkan hasil analisis dan pembahasan pada Bab IV yang telah dibuktikan, maka kesimpulan dari penelitian ini adalah terdapat pengaruh yang positif dan signifikan antara kualitas pelayanan terhadap kepuasan nasabah pada PT. Bank Negara Indonesia Tbk Kantor Kas Binuang yang menunjukkan nilai thitung sebesar 9.325 yang artinya $t_{\text {hitung }}>t_{\text {tabel }}(9.325>$ 1.987) dengan tingkat signifikansi $0.000<$ 0.05.. Jika kualitas pelayanan semakin meningkat maka kepuasan nasabah PT. Bank Negara Indonesia Tbk Kantor Kas Binuang juga akan meningkat, sebaliknya jika kualitas pelayanan yang ada di PT. Bank Negara Indonesia Tbk Kantor Kas Binuang semakin menurun maka kepuasan nasabah juga dapat menurun.

\section{Daftar Pustaka}

Cahyani, Dwi Putri, 2016, Tingkat Kepuasan Nasabah Pada Bank Muamalat Makasar, Skripsi, Universitas Hasanuddin, Makasar

Komaruddin, Muhammad, 2014, Analisis dan Penerapannya, Penerbit Raja Grafindo, Jakarta

Kotler, Philip dan Kevin Lane Keller, 2014, Manajemen Pemasaran, Edisi 13, Jilid Satu, Penerbit Erlangga, Jakarta

Parasuraman, dkk, 2015, Manajemen Pemasaran Jasa Di Indonesia, Analisis Perencanaan, Implementasi dan Pengendalian (Edisi pertama). Salemba Empat, Jakarta

Lupiyoadi, Rambat, 2016, Manajemen Pemasaran Jasa:Teori dan Pratek, Salemba Empat, Jakarta

Mochtar, Noor Alabionsyah, 2014, Analisa Kepuasan Nasabah Terhadap Pelayanan Kredit (KUPEDES) Pada BRI Bangkuang Raya Tamiang Layang, Skripsi, Sekolah Tinggi Ilmu Ekonomi Pancasetia, Banjarmasin

Nasution, M. Nur, 2016, Manajemen Jasa Terpadu, Ghalia Indonesia, Bogor

Rangkuti, Freddy, 2017, Measuring Customer Satisfaction (cetakan ketiga), PT.Gramedia Pustaka Utama, Jakarta
Saladin, Djaslim, 2017, Bauran Pemasaran dan Loyalitas Konsumen, Cetakan Ketiga, Penerbit Alfabeta, Bandung

Suparmi, 2017, Analisis Kepuasan Nasabah Pada BRI Syariah Cabang Makasar, Skripsi, Universitas Hasanuddin, Makasar

Sunarto, 2013, Manajemen Pemasaran Dalam Konsep, Edisi Kelima, Penerbit Erlangga, Jakarta

Tjiptono, Fandy, 2014, Strategi Pemasaran (Edisi II), Penerbit Andi, Yogyakarta

Umar, Husen, 2015, Statistik dan Metodelogi Penelitian, Pusaka Baru, Jakarta 